jects are the most successful in the average society. The social part of the county society is not the least important, and should not be despised. To know one's fellow workers helps us and them.

What is the effect of the county and state associations on the individaal nurse? All of us who have had the chance to step out of our own little round of interests by being sent as delegates to some of these meetings know how the horizon widens as we look about us. Doubtless you have all had such expcriences. Your state meetings have drawn you out of your perplexities and prejudices, you have met and admired. fine women from other schools than your own, and you have gone home with a better balanced mind and a warmer heart.

But think of the nurses throughout the state who cannot get as far from home as the state meeting. Think of the strangers among you who have no alumnx association near at hand. What can you do for these? Can't you help shake them out of their ruts, help open their eyes, and broaden their interests by getting all the nurses of a region together in a county society and making the meeting so good and the work done so important that no onc will want to miss being a part of it all?

It can't be done without some self-sacrifice. If there are flourishing city associations well established and growing, they will have to stretch their arms a little and take the whole county in. The alumnæ associations will have to subordinate their work a little, and throw their energies heartily into the more central body. There may be some twinges of regret, but there will be compensation. The surprising thing in this world is that a little self-forgetfulness brings so much unexpected blessing.

\title{
OBSTACLES IN THE PATH OF THE SCHOOL NURSE
}

By CHRISTINE RUSSELL KEFAUVER

Graduate of St. Mary's Hospital, Brooklyn, N. Y.

Mucil has been written of late on this problem of school nursing. It has consisted largely of academic discussions which treated of the need of the school nurse, the effects on the child, and of the waste which the neglect of the child, the most valuable of all our resources, entails to the people of this and future generations. All this is very true and very interesting and very instructive, but $I$ beg to present a view which seems hitherto to have been overlooked-the difficulties of the situation, not from the standpoint of the scientist, or the statistician, but from 
the more intimatc standpoint of one of the real insiders, the school nurse herself.

I have been for several years deeply interested in the subject of medical inspection in the public schools, and have seen the sys.'m under which it is carried on in several of the eastern cities, besides having been personally identified with the work in Chicago during the past year.

In every case I have been forcibly impressed wit! the importancc of the place occupied by the nursc in supplementing the work of the medical inspector; and still morc so with the obstacles in the way of her getting the best possible results.

I will try to describe a few of these obstacles as I, and others, havc encountered them in Chicago, where they are probably more numerous because of the newness of the work. Our first difficulty here arose over the difficulty of money. The school nurses were originally an emergency measure and the appropriation provided was only sufficient to pay our salaries for three months. By the end of that time the nurses had so demonstrated their ralue, not only as preventive and curative agents where the question of communicable diseases was concerned, but also as valuablc auxiliaries of the truancy department, that strenuous efforts were made to have us retained as a permanent branch of the health department. Much opposition was manifester to this being done, and the sources whence the opposition emanated served to show the lengths to which greed and unreasoning prejudice against any new departure can carry even educated people.

At first a number of school teachers, and even principals, objected, but a very short time served to show that these could be classified into threc groups. Those who did not understand just what school nursing meant and feared that it would result in interfering with the school routine, or lower the attendance, when convinced that such was not the case became ardent advocates of it. Next came those who feared that part of the funds necessary to maintain the work were to be deducted from the already slender appropriation of the Board of Education.

The third group consisted of those who were old-fashioned and firmly believed that measles, scarlet fever, and diphtheria were dispensations of Providence, which every one had to bear sooner or later, and the sooner we had them and got over it the better; also that pediculi, ringworm, impetigo, and scabies were afflictions of childhood, unpleasant to be sure, but not to be avoided. The memhers of this group withdrew into their shells, as it were, and dismissed the whole subject of medical inspection as one more "fad" which had been thrust upon them. 
'They neither assisted nor hindered, they simply ignored. They saw none of the good accomplished, but mentally filed for future reference any mistake or unpleasantness which occurred.

I astly (and to their credit this group was extremely small) cane a few narrow individuals who felt that the school and all it contained was their personal property, and that any person coming into it must necessarily be guided by what they thought. They preferred to say whether a child should be excluded or re-admitted to school; what rooms routine inspection should be done in and how frequently. In short, they wished to conduct the medical inspcction of the pupils, not according to the ideas of the medical inspectors and school nurses, whose professional training qualified them for the work, but according to their own personal whims and fancies. Fortunately, as I have said, such people were rare, and as there were only 42 school nurses in all, and this number could not possibly cover all the public schools in Chicago, the Board of Health dropped all those schools where the principals and teachers refused to co-operate, and transferred the nurses to schools where the teachers and principals appreciated the work they were trying to do.

Another thing which complicated the work was the attitude of the parents. As I have said, school nursing is new in Chicago, and being so, a large amount of educational work had to be, and still has to be, done before the general public realizes that it is the gainer and not the loser by the new order of things.

We have here, as in New York, a large foreign element, and it is among them that most opposition is met by the nurses to the work they are trying to do. 'The Stock Yard district of Chicago is made up almost entirely of Polish, Lithovanian, Bohemian, and some Swedish emigrants hardly any of whom speak or understand English. These people are all of the poorest peasant classes and, with the exception of the Swedes, have been for ages subject to the cruel despotism of Russian rule and are ignorant and suspicious to an astonishing degree. They are absolutely unable to grasp the idea of any person doing anything for them merely from a desire to help them, and they are sure the nurses and doctors must be getting something out of it " on the side." The Poles, especially, are sullen and indifferent, and it is almost impossible to have even the most glaring defects remedied except by the persistent efforts and longcontinued visits of the nurse.

Adenoids and enlarged tonsils, not being external defects, are calmly ignored, and no amount of argument will convince the majority of the parents that our desire to have them removed is not a scheme whereby 
we are in some unexplained way the gainers. Glasses they dislike, and as far as possible refuse to provide, while such a thing as vermin is dismissed with a calm shrug and a stare of ox-like surprise that we should concern ourselves with so trivial a matter.

The Swedes and Bohemians are brighter and more progressive and take readily to the idea of remedying their children's defects, while vermin are comparatively rare amang them. Then, too, they are not cursed with the drink evil as the Poles and Lithovanians, and so their homes are cleaner and better, their children are better fed and clothed, and the filth diseases of scabies, impetigo, favus, etc., are much more rare among them. It is, however, a curious fact that throat affections. such as hypertrophied tonsils and adenoids, are much more prevalent among the better class of children than in those in very poor circumstances. Perhaps some one can tell us why.

The last and greatest obstacle encountered by the nurses was-the medical profession. This was really the " unkindest cut of all" as it was one quarter from which they felt they had a right to expect encouragement and support. The trouble started almost immediately and with the medical inspectors.

Doctors had been employed in the public schools as medical inspectors for-some time, and had been examining children and sending home a card to the parent on which the physical defect was noted and the parent adrised to seek treatment. They also cxcluded contagious diseases, examined children who had been excluded before re-admitting to school, and placarded houses where contagious cases were quarantined. As the salary was only $\$ 50$ a month, the position did not present great attractions from the financial standpoint, and the doctors who took it up felt they were doing their full duty if they ran into a school for a few minutes, asked if there were any children to see them, and ran out again. The medical inspectors were largely recruited from three classe: : The young doctor just starting practice, who wanted something that would pay his rent and probably throw a patient or two his way till he got on his feet and could afford to give his whole time to his own practice; the old or middle-aged man who, after years of struggling practice, yet could not make both ends meet and took this to piece out; and the successful practitioner who had taken up the work when he needed the money, and then as the great scope of its possibilities opened out before him, stayed in it for the love of the work itself rather than for anything it could bring him, and strove in every way to be of most value to the school fortunate enough to have him for a medical 
inspector. Such a doctor gave fully of his time and services, and the paltry remuneration which he received could in no way compensate for the good accomplished through his efforts. From doctors such as these the nurses experienced only courtesy and a keen desire to co-operate with and encourage them in every way in the work they were trying to do, and they stood their staunch friends in the stormy medical meetings in which they were accused of every crime under Heaven, up to the capital one of taking the bread out of the mouths of the starving medicos.

With the very poor of the school children the nurses were able to do a great deal if they succeded in gaining the parents' consent. The dispensaries, the bureau of charities, the visiting nurse association, all gave generous aid to those for whom they sought it. It was when they came to the middle class, the people with a little means, that they struck their first real snag.

'To illustrate: One of the nurses went to a child's home to investigate a case of hypertrophied tonsils and adenoids referred by the medical inspector as needing treatment. The people were Swedes and lived in a comfortable little apartment for which they paid twelve dollars a month rent. The father earned forty dollars a month and there were six children besides himself and wife, and as he was frugal and sober they reened to be able to get along nicely, but there was no surplus for luxuries. The nurse inquired if they had a family doctor, and upon their nientioning a doctor who treated them when they required it, advised then to consult him concerning an operation. Incidentally she discorered that the eldest girl was badly in need of glasses. She advised them to see to this also, which they agreed to do. Two weeks later she received a request from the parents to call and see them. They told her they had consulted their doctor and he wanted fifteen dollars to remove the tonsils and adenoids and would not do it for a cent less. The oculist, to whom they had taken the eldest girl, had wanted seven dollars and a half to fit her with glasses. That meant twenty-two dollars and a half to remedy the defects of two children. That left seventeen dollars and a half out of a month's salary of forty dollars; deduct twelve dollars for rent, that left five dollars and a half for the expenses of a family of eight persons for one month. It was clearly impossible.

Meanwhile the lack of glasses and the consequent eye-strain was ruining the nerves of the girl, and keeping her back in school, while the adenoid growth of the boy had been so long neglected that he was already two years behind his grade. The nurse took the boy to a free dispensary, where upon the payment of fifty cents to cover the cost of the ansesthetic, his adenoids and tonsils were removed by a competent doctor, while 
the girl's eyes were treated at the samc dispensary and glasses gotten for the modest sum of two dollars. Thus for two dollars and a half these children were returned to school better able to do their work and compete with their comrades, and the parents were saved the remaining twenty dollars which they would otherwise have had to pay and which they could ill afford.

Now, what was the result The medical inspector, who in this case was also the family doctor, denounced the school nurses at a medical meeting and declared that they were taking to the dispensaries patients well able to pay a family physician for treatment.

This is merely one instance-here is another. A certain medical inspector in one of the schools left nothing but cards reading " needs glasses." Upon calling at the children's homes it was found that in twenty-seven cases, every case was his own private patient. Of course the nurse was obliged to refer these facts to him, although he was not an eye specialist, and he charged them a dollar each to verify a diagnosis he had already made in school and then referred them to a friend of his to get the glasses. If this isn't " graft," what is it?

The nurses are fortunate in having a most just Board of Health, and the evidence in these cases, after careful investigation, resulted in the dismissal of the men in question.

Now the question is this: Given a child with a serious physical defect that is going to keep him back in school and consequently in life; his parents are too ignorant to see the necessity of spending fifteen or twentyfive dollars for a thing that "never makes him sick," or else they have a lurge family and feel that they cannot afford it, but they are willing to pay the small fee required by the dispensary for an operation or glasses. Now, out of regard for the feelings of the private doctors, are those children to be allowed to retain these defects; or are the doctors to reduce their fees within the reach of the people of small means; or are the school nurses to have these defects remedied in the dispensaries at dispensary rates? It seems to be an open question. I confess I am strongly prejudiced in favor of the children.

To sum up then, the two great obstacles with which the school nurses have to contend are greed and ignorance. The former only time and the contempt of their fellowmen will eradicate. The latter is to be combated by a persistent campaign of education directed in the interest of the parents and teachers. I have looked into this phase of the question pretty thoroughly in the past year, and tried the educational scheme with great success. I have first endeavored to interest the principal, and after doing so, have gained his consent to invite the mothers to the school on a 
certain afternoon, and then I have endeavored in simple practical language to explain to them exactly what school nursing meant; what tonsils and adenoids are, and above all, what their neglect results in; also how eyes are tested in school, and the nervous troubles which their neglect results in. In the schools where "mothers' meetings" are encouraged this is a simple matter, but where those things are unknown one has to depend upon the courtesy of the teachers and principals to make the necessary arrangements and get the mothers to attend.

I have found that the simple test of displaying the lettered card by which the children's eyes are tested, on the blackboard in front of a room full of mothers, and requesting them to study it while I was speaking, and see how many of them were unable to read to the normal limit, has done more to show them how necessary glasses really are for their children than any amount of home instruction.

Also, when speaking to them in a group in this way, they are sure to discuss it afterward among themselves, and as there are always one or two present whose children have been helped by an operation, or glasses, they naturally quote their experience, and it has great weight with other mothers.

When speaking to them in this semi-informal way I encourage them to ask questions and discuss their doubts and theories and try to show them where they are wrong. There is nothing technical about it as in a doctor's lecture, and being accustomed to see the nurse every day, they feel more or less acquainted with her and more disposed to heed what she tells them.

Of course all this takes time and patience, but it pays in the long run. It is easier to tell fifty women one thing at one time than to go to fifty homes and repeat the same thing fifty times, and it saves time.

Another thing to be remembered is, that different communities have to be appealed to differently. In a community largely American, national pride, a desire to have the American child the equal, if not the superior, of every other should be dwelt upon.

In a Swedish community, it should be shown how the removal of physical defects renders the child brighter and more successful in life.

In a Polish district, where the sole desire of the parents is to get the child out of school at fourteen and set him to work, it should be pointed out that physical defects if unattended will result in keeping him a year or two longer in school.

In a Jewish district the great waste from a financial standpoint can be dwelt upon. The cost of the public school system, the cost of raising a child from birth to the working age, and the waste in dollars and cents 
if, through neglect of a remediable defect, the child's earning capacity is practically cut in half. Above all the public needs to be constantly educated in one thing: that is, that it. as a taxpayer, is maintaining the boards of education and of health, and, that $i t$ has the greatest reason for demanding the highest interest on the capital invested. Such interest to be returned to it in the form of children who, upon leaving the public school, shall not only have gained an education, but shall take into the world with them healthy bodies which will enable them to apply that education to the best possible advantage to themselves and the community to which they belong.

\title{
HOSPITAL VIGNETTES : THE OLD-TIME WARDMAID
}

\author{
BY GEORGIANA J. SANDERS
}

Grudunte of the Manchester General Children's Hospital, England

HAS she altogether passed away, that austere, tyrannical, talkativa mirncle of cleanliness, with her immense respect for properly constituted authority and her profound contempt for each new batch of "perbationers"?

Who trained $u s$ in thosc far-away days in the way we had to go? The remote lady in the office in whose presence we stood and suspended labor? The busy head nurse, tied up, it seemed, everlastingly in the doctor's? Our seniors who saw to it, in self-preservation, that we soon knew when to fetch and how to carry, and various practical parts of our work that otherwise devolved on them? (O) the doctors who showed us mysterious spots through the microscopc and supplied us unasked with strikingly irrelevant information?

They must all certainly have had their uses. But the authority we feared, before whose ready tongue and contemptuous glance the stoutest quailed, she who taught by experience, expected less than nothing from ns, and yet exacted standards it was hopeless to attain, this authority reigned in scornful independence in the ward kitchen, emerging punctually as clock-work twice a day to sweep the wards or scrub the lavatories. Did it matter to her that you had not finished making your beds? Not a bit: it was sweeping time. Or had you perhaps finished early and would fain have begun your dusting? Well, I don't believe any one ever suggested such a revolutionary idea: it was the peace of the whole day in the balance against ten minutes' extra margin to the morning rush of work.

Do you remember your first night on night duty? The mysterious 